TITLE:

\title{
GONIONEMUS SUVAENSIS : STRUCTURAL CHARACTERS, DEVELOPMENTAL STAGES AND ECOLOGY
}

AUTHOR(S):

Goy, Jacqueline

CITATION:

Goy, Jacqueline. GONIONEMUS SUVAENSIS : STRUCTURAL CHARACTERS,

DEVELOPMENTAL STAGES AND ECOLOGY. PUBLICATIONS OF THE SETO MARINE BIOLOGICAL LABORATORY 1973, 20: 525-536

ISSUE DATE:

1973-12-19

URL:

http://hdl.handle.net/2433/175760

RIGHT: 


\title{
GONIONEMUS SUVAENSIS: STRUCTURAL CHARACTERS, DEVELOPMENTAL STAGES AND ECOLOGY
}

\author{
JACQUELINE GOY \\ Muséum national d'Histoire naturelle, 57 rue Cuvier, \\ 75005 Paris, France
}

With 2 Text-figures and 20 Photographs

The species Gonionemus suvaensis, established by AGASSIZ and MAYER (1899) on specimens collected in Fiji Islands, has been then separated from this genus and called Scolionema by KISHINOUYE (1910), but KRAMP (1965) reports it again under the genus Gonionemus because the distinct characters for Scolionema are not significant enough to regard the genus as a separate one, though, in 1968, the same species is treated under the generic name Scolionema when this author describes the Indo-Pacific specimens. Many works about Gonionemus suvaensis are either diagnosis with data on localities and seasonal occurrences or papers mentioning distributions only, while detailed morphological descriptions have been missing. The present paper is a monograph on the Mediterranean specimens, giving their structural characters, developmental stages and ecology.

\section{Material and Methods}

The Bay of Villefranche-sur-mer (France) has been chosen as a sampling ground, for PICARD (1955) proved that this species is very abundant there. There is such a submarine topography that goes down to $50 \mathrm{~m}$ or so, beautiful sea-grasses can grow there and it is in that peculiar biotope that Gonionemus suvaensis is found.

The sampling was made by hauling behind a boat a triangular net whose opening is one meter wide and whose filtering part $1.40 \mathrm{~m}$ long and made of stramin net with 6 meshes $/ \mathrm{cm}$. One side of the opening is well ballasted so that the boat, going dead slow, draws the net through the top of plants, on blades of which the animals are resting.

The samples collected were supplied in a glass vessel, with a considerable amount of sea water and kept for on hour in the dark. Then the limnomedusae swam up actively into the water from the leaves. By taking successively a part of the water out of the glass vessel, the medusae could be seen with the naked eye; they were taken out, counted and measured under a stereomicroscope when alive and extended.

The samples attained 35 , collected as far as possible every week in summer, but less regularly in the rest of the year. 


\section{Description of the Mediterranean Specimens}

PICARD (1955) has well studied this species at Villefranche and given the description of 7 developmental stages of the medusa according to the increase in number of the marginal tentacles and closed vesicles or statocysts, and to the position of gonads over radial canals. He has insisted, in contrast with what is seen in the other parts of the world, that no budding occurs over the gonads that therefore look smooth.

The 929 specimens collected in 1963 and 1964, corroborated well the data given by PICARD (Photo 1), though some were older than the stage VII of this author and belonged to the stage VIII defined in my previous paper (GoY, 1972). Thus, in spite of the presence of functional gonads, the multiplication of new tentacles is not always inhibited. The youngest medusae found in the material were at the stage IV of PICARD: with 16 tentacles with an adhesive pad and 8 smaller ones without any pad, and with gonads not yet functional. The sorting with the naked eye is probably responsible for the lack of younger stages. The sexes were recognizable only when the diameter of the umbrella reached 4 to $4.5 \mathrm{~mm}$ and the ornamentation acquired 32 tentacles, namely of the stage VI of PICARD.

The male gonads seem to appear earlier than the female gonads and will become functional at the stages VII and VIII. They cover only the distal $1 / 3$ of radial canals, and the female gonads are wreathed by ovules, though the gonads never show either folded nor papillose appearance described by different authors, especially BIGELow (1909) and UCHIDA (1929). The male gonads are ribbon-shaped and white, while the female gonads are longer and pinkish, with ovules in two rows.

The old tentacles carry adhesive organs (Photo 3), a kind of pad, well described by WeILL (1938). WeILL states that these organs are situated in distal portion, but they are proximal on the specimens of Villefranche and the tentacle has only some nematocysts between the umbrella and the pad. Though UCHIDA indicates that the gonads appear when the number of tentacles reaches 40 , the formation of gonads begins earlier in the Mediterranean specimens.

The coloration is: pink for the stomach with 4 green spots at respective bases of radial canals, green for 4 radial canals, pink for the base of tentacles, pink for the female gonads, but white and with a greyish shade for the male gonads.

The Mediterranean specimens are smaller and the number of tentacles remains low; the number does not surpass 48 , whereas it is reported to attain 70 in Japanese waters or in the Pacific. This is perhaps a case of neotenic form due to shortening of life cycle: the medusae having only a few months of optimal conditions. In rearing, they live for nearly two months. In the sea, a decrease in the diameter of specimens is noticed during the seasonal occurrence, this seems to suggest a succession of medusae of different generations. 


\section{Distribution}

Sampling was done all the year round at different points of the bay, so that the cycle and migration of population of this species in the bay can be recorded. Sampling with a plankton net down to $3 \mathrm{~m}, 20 \mathrm{~m}$ and $50 \mathrm{~m}$ was negative. This species is not planktonic, then sampling by a "moving net" among the sea-grasses was positive during the summer season. In May, the first specimens appeared only upon the sea-grasses and this kept on till October; but in winter no specimen was collected. Consequently, this is a summer species and a neritic species limited to the above-mentioned special biotope with growing sea-grasses.

The greatest abundance was found in June and July (Fig. 1).

The change in bell diameter by months is as follows:

$\begin{array}{lcc} & \text { Maximum diameter } & \text { Most frequent diameter } \\ \text { June } & 7 \mathrm{~mm} & 4 \text { or } 4.5 \mathrm{~mm} \\ \text { July } & 6 \mathrm{~mm} & 3 \text { or } 4 \mathrm{~mm} \\ \text { September } & 5 \mathrm{~mm} & 3 \text { or } 3.5 \mathrm{~mm}\end{array}$



Fig. 1. Monthly variation in number of medusae in relation with temperature and salinity.

$\Delta$ medusae; $\mathrm{T}^{\circ} ; \triangle \mathrm{S} \%$

The sexual maturity takes place before the greatest size is attained. Every month, there is a great weekly variation in abundance, with the maximum at full moon (Fig. 2). The lunar rhythm in the liberation of medusae by hydroids has already been observed in other species, especially Obelia (ELMHIRST, 1925). . This is seemingly a phenomenon common to all hydromedusae produced by hydroids as it is a common phenomenon in the life cycle of such lower animals as worms.

The study of hydrographical conditions shows the existence of two seasons in the bay (Fig. 1): winter to spring when the water is cold, between $12^{\circ} 5$ and $17^{\circ} \mathrm{C}$ in 
temperature, and summer to autumn when the water is warmer, higher than $17^{\circ}$ and up to $24^{\circ}$ or $27^{\circ} \mathrm{C}$.

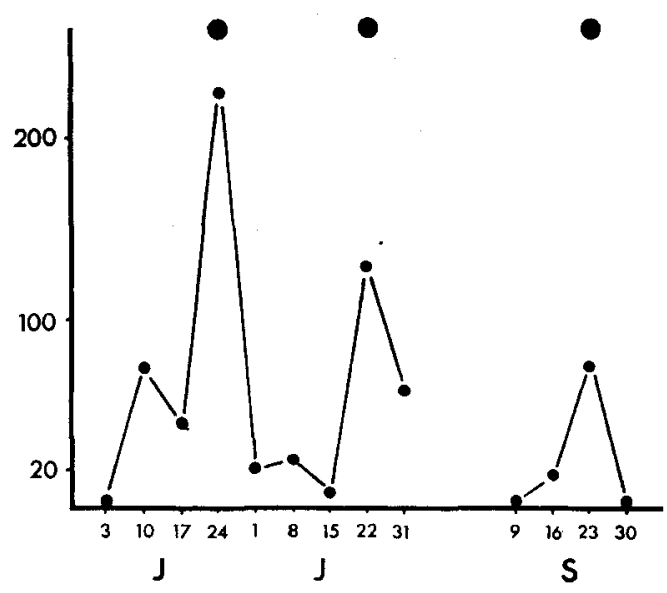

Fig. 2. Weekly variations in number of medusae. full moon

In spring, the rainfalls bring about a strong dilution of the sea water, and this is more significant in this shallow area of the bay, while in autumn the salinity rises to $38 \%$. The high salinity goes on in winter, for there are few precipitations, but suddenly it drops to $37,5 \%$ as soon as the spring heavy rainy season starts. It is just after this decrease in salinity that the first medusae appear upon the sea-grasses.

\section{Medusa Budding (Photo 4)}

In the literature, it is stated that the medusa buds appear on the radial canals and the gonads will develop when budding is stopped. At Villefranche, only a single specimen has been found possessing a bud between the marginal canal and a gonad. The specimen was collected on the 24th of June, 1964.

The mother medusa is at the stage $\mathrm{V}$ of PICARD, and provided with 24 tentacles with pad and 8 smaller ones without any pad, and 8 statocysts. It possesses 4 gonads on the distal part of respective radial canals, but they are not mature yet.

The bud is situated near the marginal canal, thus the position is not on the gonad, though near them. It has a manubrium, 4 radial canals, 4 long tentacles with pad, but neither gonads nor statocysts. It seems impossible to say that the bud is ready to be liberated that way.

UCHIDA points out that in Japan that the medusa buds are liberated from the mother medusa at the stage with 24 tentacles and 8 statocysts, much more advanced than the above-mentioned bud on a medusa from Villefranche.

The different position of the bud on the specimen from Villefranche, which does not appear on the gonad, existence of 4 gonads together with a bud on the mother 


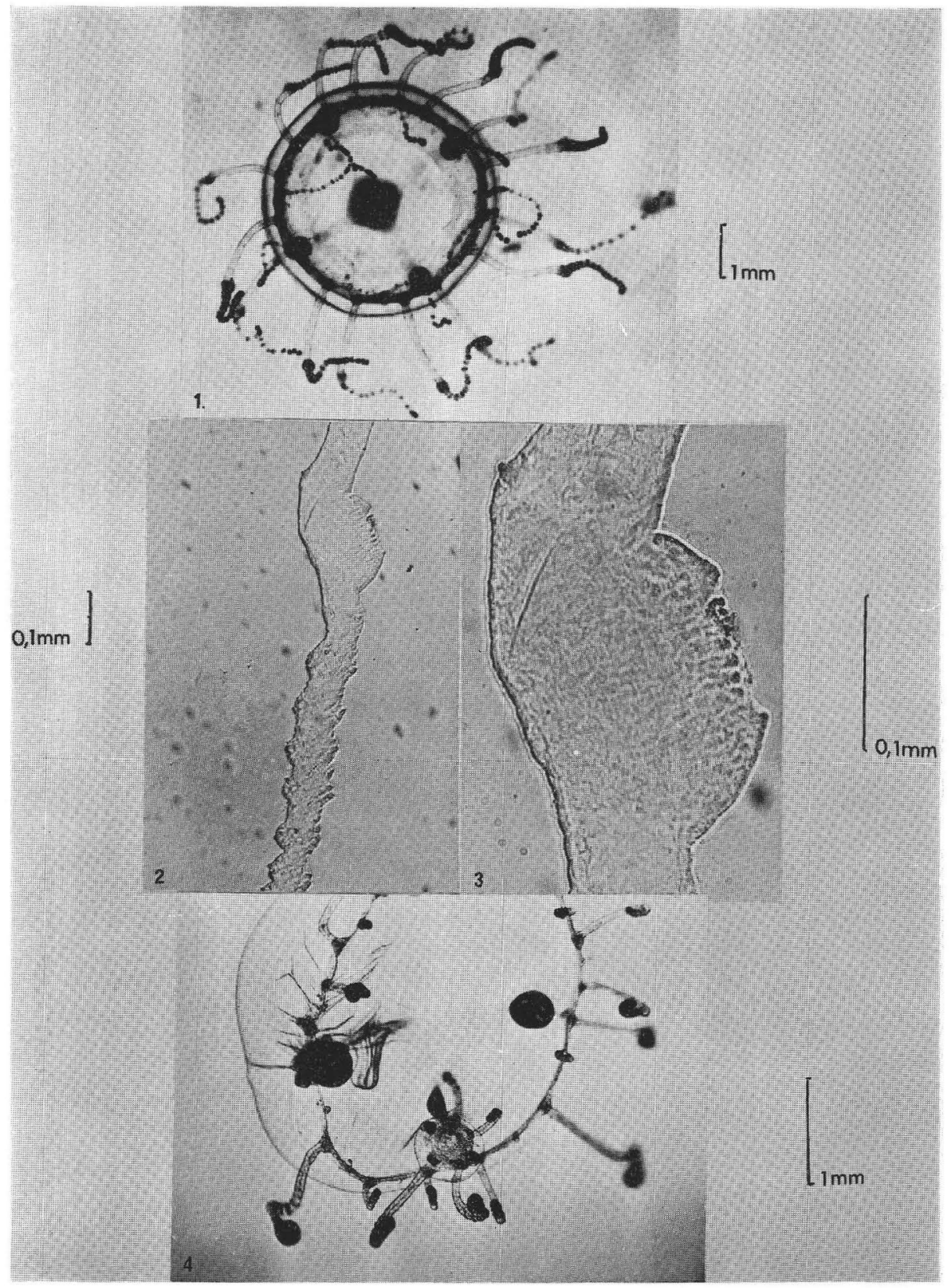

Photographs: 1-Adult medusa. 2-Tentacle. 3-Adhesive pad. 4-Medusa with medusa bud. 


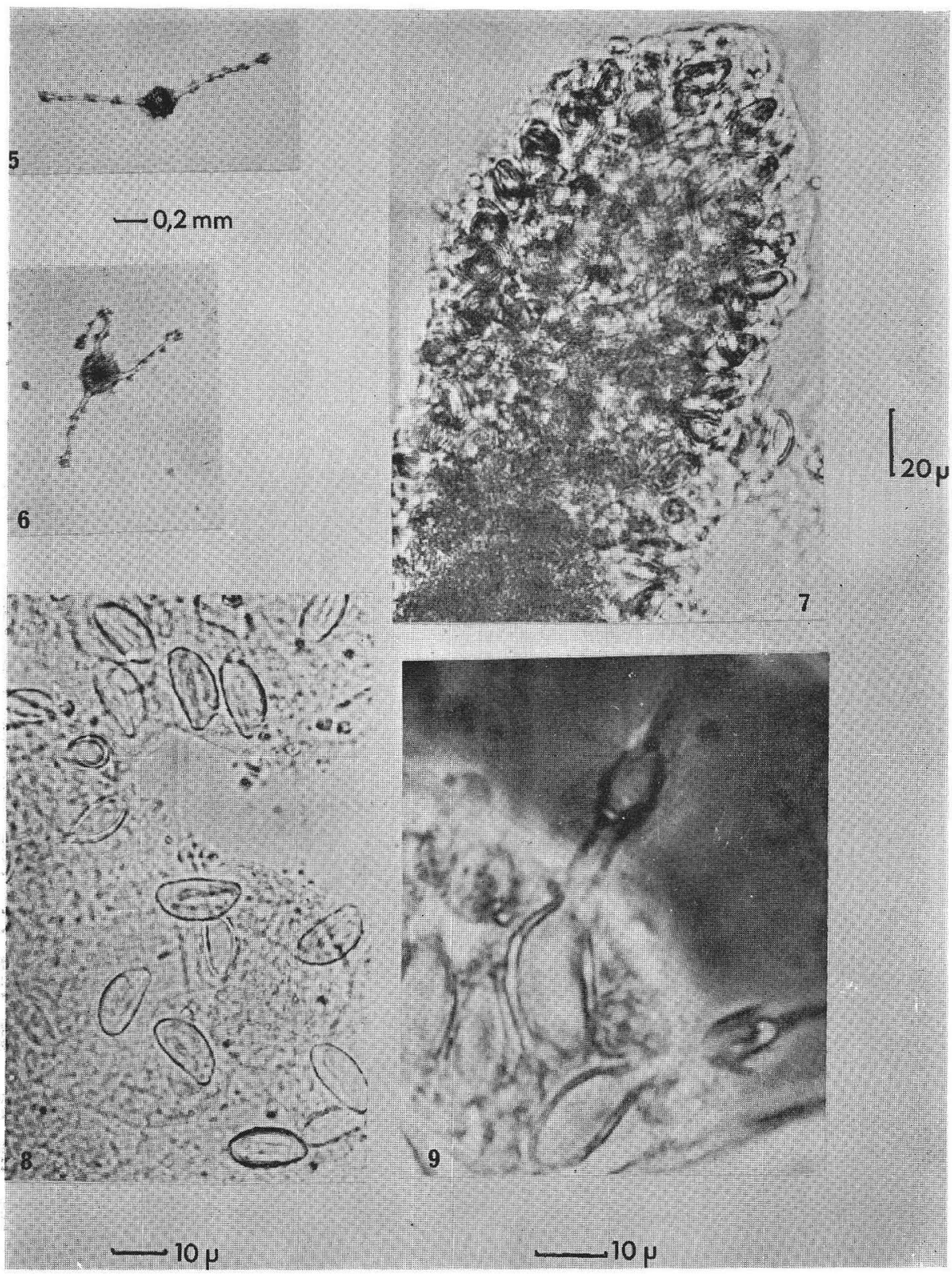

Photographs: 5-Young hydroid. 6-Hydroid with 3 tentacles. 7-Tentacle of hydroid. 8-Nematocysts. 9-Nematocysts, eurytele microbasic heterotrichous. 




Photographs: 10-Frustule bud. 11-Frustule bud. 12-Frustule. 13-Frustule. 


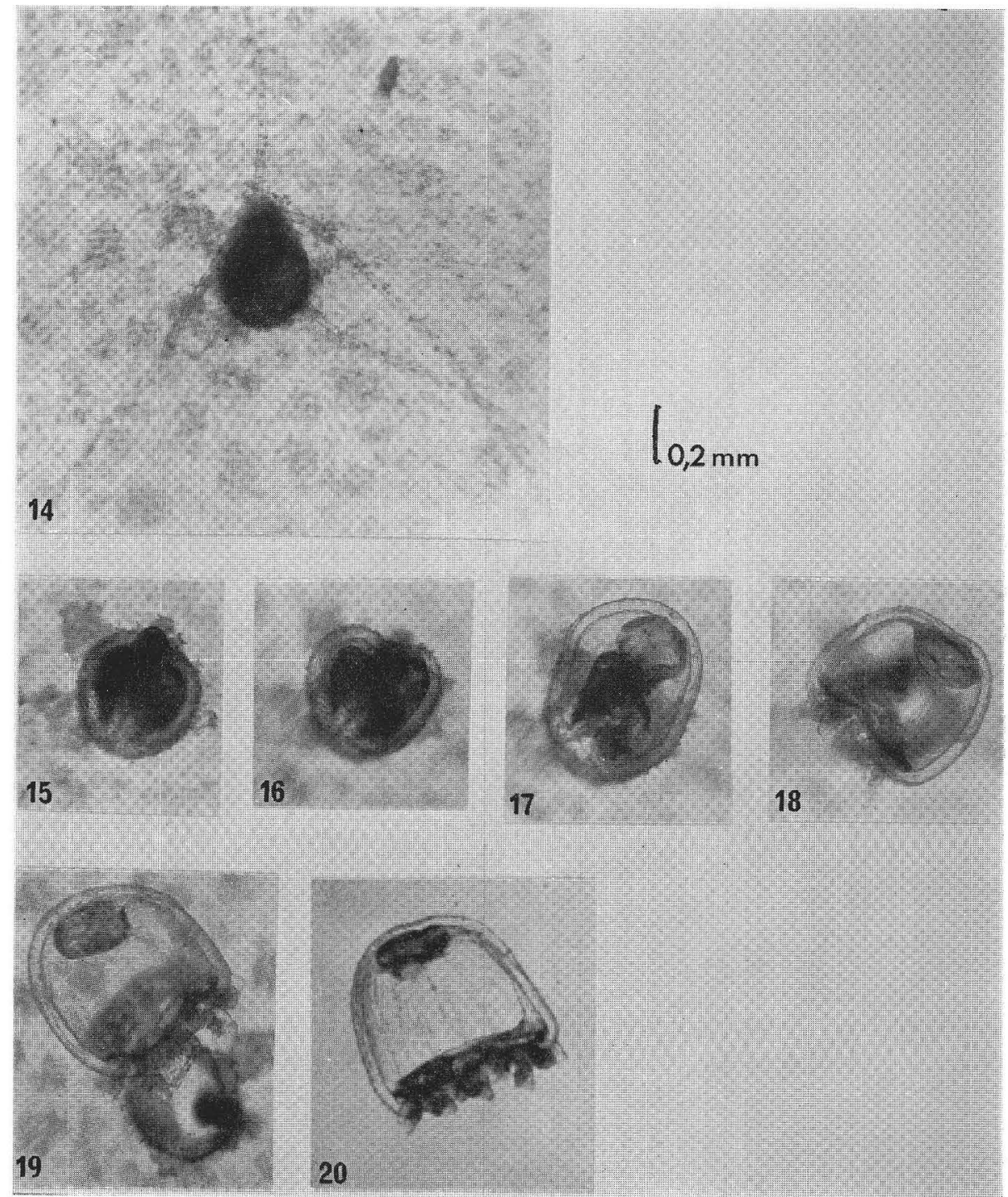

Photographs: 14-Hydroid with medusa bud. 15-19 Medusa bud. 20-Free swimming medusa. 
medusa, and the ornamentation of the bud with only 4 tentacles but no statocysts should be noteworthy. Further it may be noted that the water temperature was exceptionally high, $24^{\circ} \mathrm{C}$, in June, 1964.

Like in every population, abnormalities are shown in Gonionemus suvaensis of Villefranche in number of tentacles and position of manubrium and gonads (Goy, 1972). The most abnormal specimen may be an individual with 8 tentacles with pad, 4 statocysts, and only 2 radial canals arranged diametrically, one carrying a gonad and the other the manubrium. Such abnormalities are met with most frequently at the end of summer.

G. suvaensis entertain few parasites: among the 929 specimens observed, only two contained a cyst of cercaria in the mesogloea above the stomach and one an unidentified ostracod on the subumbrella.

\section{Feeding}

In rearing, G. suvaensis are prominently carnivorous, they are able to eat at a time 7 nauplii of Artemia just hatched, then after feeding the base of tentacles becomes reddish-brown. They can live for more than 2 months in a glass vessel without renewing the water, which will then become $50 \%$ in salinity. Without feeding, they survive by using the contents of gonads and then just before death, the mesogloea above the stomach will swell up to give the exumbrella a bulging shape.

\section{Developmental Stages}

The development has been observed on male and female medusae reared together in a glass vessel.

The ovule is about $60 \mu$ in diameter and seems to issue polar globules immediatly after liberation. It is just after that it is fertilized by spermatozoa which is about $5 \mu$ long and with a very refringent head.

The first division occurs immediatly: when the medusae of both sexes were put in together at 5 p.m., the first division occurred at 9.15 p.m. and the second at 10.10 p.m.; and on the next day the morula stage was attained without any increase in size. After a day the planulae, ciliated, didermic, and about $85 \mu$ long and $65 \mu$ wide, were found swimming. Just before swimming they whirled around slowly, then fixed themselves to the substratum and developed to hydroids.

However, the egg can become hydroids without free stage, the change taking from 2 to 12 days. The planulae fix themselves better to less clean glass vessels which look something like leaves of Zostera or Posidonia.

The hydroid has already been described (GoY, 1970): it is a single hydroid which is quickly invaded by diatoms. It does not assume the appearance of usual hydroid but looks like a flattened disk from which tentacles and buds are issued. The hy- 
postomial region is not well defined except in the course of taking foods. The nematocysts are scattered in heaps on the tentacles and are eurytele microbasic heterotrichous (Photo 5-9).

Intensive asexual budding produces frustules (Photo 10-11) in well fed conditions or resting buds by a kind of encystment in unfavourable conditions of environment. This frustules can crawl by contraction and extension (Photo 12-13); they may remain as they are for several days before fixing themselves to the substratum and changing into hydroids.

The reproduction in this way is very active: in favorable conditions, one hydroid buds out 3 frustules in a day from October to May, thus in these 240 days 700 frustules are produced and they become hydroids which then will budd in their turn.

It has been possible to observe the medusa bud on the hydroid, though it was impossible to sacrifice the material for an histological study because of its rareness: only 2 hydroids have been living for one year in a glass vessel.

\section{Medusa Bud on the Hydroid (Photo 14 to 20)}

The position of the medusa is quite similar to the site of budding frustules, but the form of the bud is different and the development to the medusa takes 4 days; the bud is spherical and rounded to the end. Inside the bud, of the tissues of the young medusa the subumbrellar and tentacular cavities are differentiated very early, then the manubrium, and the tentacles lastly. At this stage, the umbrella begins contractions which will then tear the periderm and one hour later the medusa is finally liberated.

The young medusa has the anthomedusan morphology; it is $0.7 \mathrm{~mm}$ high and 0.6 wide, with 16 tentacles ( 8 adradial tentacles with pad), 8 statocysts, numerous nematocysts scattered on the exumbrella, and a very thin umbilical canal, but no gonads but 4 slight swellings on the top of the manubrium. This corresponds to the stage I of PICARD and actually the stage of liberation. Being normally fed with nauplii of Artemia the young medusa develops as described by PICARD.

The fate of hydroid is very interesting: the hydroid after the production of the medusa bud, looks like a kind of lump, with neither tentacles nor mouth, the alteration of tissues makes the hydroid into a frustule which then fixes itself to the substratum and gives again the hydroid. In the formation of medusa bud, it seems that the tissues of the hydroid are reorganized into medusa, possibly the nematocysts of the hydroids being used again in the tentacles of the young medusa.

Here it is pointed out that this medusa bud appeared in June, while the hydroid had been fixed to the vessel since September. From September to January, the hydroid gave a lot of frustules, then it changed into a resting bud which was left uncared because it was difficult to find out the buds among the diatoms which invaded the glass vessel, the water in the vessel never being renewed. At the beginning of June 
the resting bud became again an hydroid that was then fed, and the water of the glass vessel was renewed. The water in the vessel had attained to a high salinity of $53 \%$ and thus this hydroid had to experience a sudden decrease of salinity of ambient water to $38 \%$, normal for the sea water in June. Immediatly after this decrease of salinity, the medusa bud appeared on the hydroid. In fact, this happened in the bay, too, the medusae appeared after the spring rainfalls which lowered the salinity.

The northern part of the Mediterranean Sea represents the northern-most area of distribution of this species which is regarded by all the authors as an Indo-Pacific thermophilic species. At Villefranche, it is found in a great abundance during the warm season as the free-swimming medusa, corresponding to the sexual stage of the life cycle. The species must survive the winter season in the hydroid form, frustule, or resting bud. The life cycle is metagenetic, though the hydroid form has never been recorded at Villefranche. Now, it is known that the hydroid form exists: it is single, undersized, carrying only 2 to 5 tentacles, and produces at a high rate three kinds of buds. These are actually characters of Limnomedusa and the development is quite similar to that of Gonionemus vertens A. AGASSIZ 1862 described by JOSEPH in 1925.

The geographical position of Villefranche $\left(43^{\circ} 42^{\prime} \mathrm{N}\right.$ and $\left.7^{\circ} 19^{\prime} \mathrm{E}\right)$ points out that this locality in a septentrional part of the zoogeographical area and this perhaps explains the absence of medusa bud on the gonads of medusae. However, the occurrence in the warm water season of a single specimen carrying medusa bud shows that this reproduction is possible, though it is limited to the season of favorable hydrographical conditions. The geographical area of this species is certainly bordered in the north and the south by an area where the medusa has no asexual reproduction by budding.

Many thanks to C. Onténiente, N. Salines and F. Humbert for their assistance. Photograph 4 from the Photothèque of Station zoologique, Villefranche-sur-mer; all the other photographs from the Photothèque of the laboratory "Pêches outre-mer". Some of them are not very clear because many diatoms were attached to the bottom of the glass vessel.

\section{BIBLIOGRAPHY}

Agassiz, A., and Mayer, A. G., 1898. Acalephs from the Fiji Islands. Bull. Mus. comp. Zool. Harvard, 32, (9), 157-189, P1. 1-17.

Bigelow, H. B., 1909. Rep. Sci. Res. Exped. Eastern Tropical Pacific U.S. Fish Comm. Steamer 'Albatross' 1904-1905. XVI. Medusae. Mem. Mus. comp. Zool. Harvard, 37, 1-243, pl. 1-48.

Bouillon, J., 1957. Etude monographique du genre Limnocnida (Limnoméduse). Annls Soc. Roy. Zool. Belg., 87 (2), 252-500.

GoY, J., 1970. Sur le bourgeonnement de trois Hydroméduses: Eucodonium brownei HarTLAUB 1907, Phialidium mccradyi (Brooks 1888) et Scolionema suvaense (A. AgAssiz et MAYER 1899). C. R. Acad. Sc. Paris, 270, 1392-1395.

—, 1972. Les Hydroméduses de la mer Ligure. Bull. Mus. Hist. nat. Paris, $3^{\mathrm{e}}$-série, 83, (sept.oct., 1972), Zool. 62, 965-1009.

JosePH, H., 1925. Zur Morphologie und Entwicklungsgeschichte von Haleremita und Gonionemus. Ein Beitrag zur systematischen Beurteilung der Trachymedusen. Z. wiss. Zool., 125, 374-434. 
KishinouYe, K., 1910. Some medusae of Japanese waters. J. Coll. Sci. Tokyo, 27, (9), 1-35.

Kramp, P. L., 1965. Some medusae (mainly Scyphomedusae) from Australian coast waters. Trans. Roy. Soc. S. Aust., 89, 257-278.

, 1968. The Hydromedusae of the Pacific and Indian Oceans. Dana Rep., 72, 1-200.

PiCARD, J., 1955. Nouvelles recherches sur les Hydroméduses des herbiers méditerranéens de Posidonies. Rec. Trav. Stat. mar. Endoume, 15, 59-71.

UCHIDA, T., 1929. Studies on Japanese Hydromedusae: 3 Olindiadidae. Annot. Zool. Jap., 12, (1), 351-373.

WeILl, R., 1938. Une méduse tropicale dite indopacifique, Gonionemus suvaensis AG. et MAYER, dans 1'Océan atlantique (Iles Bermudes). Bull. Soc. zool. Fr., 63, 33-41. 